LP improved by conventional treatment or discontinuation of drug.

In summary, physicians should be aware of the potential development of such cutaneous adverse events when administrating nivolumab therapy.

\section{CONFLICTS OF INTEREST}

The authors have nothing to disclose.

\section{ORCID}

Se Jin Oh, https://orcid.org/0000-0001-7525-4740

Young Hwan Choi, https://orcid.org/0000-0003-4177-7724

Hyun Jeong Byun, https://orcid.org/0000-0002-4354-5655

Seung Hwan Oh, https://orcid.org/0000-0002-0685-0562

Ji-Hye Park, https://orcid.org/0000-0002-6699-5202

Jong Hee Lee, https://orcid.org/0000-0001-8536-1179

Dong-Youn Lee, https://orcid.org/0000-0003-0765-9812

Joo-Heung Lee, https://orcid.org/0000-0002-1121-2055
Jun-Mo Yang, https://orcid.org/0000-0003-0656-8046

\section{REFERENCES}

1. Hofmann L, Forschner A, Loquai C, Goldinger SM, Zimmer L, Ugurel S, et al. Cutaneous, gastrointestinal, hepatic, endocrine, and renal side-effects of anti-PD-1 therapy. Eur J Cancer 2016;60:190-209.

2. Ellgehausen $P$, Elsner P, Burg G. Drug-induced lichen planus. Clin Dermatol 1998;16:325-332.

3. Goldsmith LA, Katz SI, Gilchrest BA, Paller AS, Leffell DJ, Wolff K. Fitzpatrick's dermatology in general medicine. 8th ed. New York: McGraw Hill Medical, 2012:304.

4. Komori T, Honda T, Irie H, Otsuka A, Kabashima K. Lichen planus in irradiated skin during nivolumab treatment. Acta Derm Venereol 2017;97:391-392.

5. Komori T, Honda T, Irie H, Otsuka A, Kabashima K. Multiple erosive lichen planus preceded by solitary lichen planus after combination therapy with nivolumab and radiation. J Eur Acad Dermatol Venereol 2017;31:e382-e384.

\title{
Alitretinoin Treatment for Gefitinib-Induced Paronychia
}

\author{
Soo Young Lee, Jin-Wou Kim, Dong Soo Yu, Young Bok Lee \\ Department of Dermatology, College of Medicine, The Catholic University of Korea, Seoul, Korea
}

\begin{abstract}
Dear Editor:
Gefitinib is an epidermal growth factor receptor (EGFR) inhibitor used for various cancers, especially lung cancer. It is known to affect epidermal keratinocyte of skin and commonly induce variable dermatologic reactions including follicular and pustular rash, paronychia and fissuring, hair changes, dry skin, hypersensitivity reactions, and mucosi-
\end{abstract}

\section{Received March 27, 2018, Revised May 24, 2018, Accepted for publication May 26, 2018}

Corresponding author: Young Bok Lee, Department of Dermatology, Uijeongbu St. Mary's Hospital, College of Medicine, The Catholic University of Korea, 271 Cheonbo-ro, Uijeongbu 11765, Korea. Tel: 82-31-820-5025, Fax: 82-31-846-4799, E-mail: lyb80@catholic.ac.kr ORCID: https://orcid.org/0000-0002-8642-2479

This is an Open Access article distributed under the terms of the Creative Commons Attribution Non-Commercial License (http://creativecommons.org/ licenses/by-nc/4.0) which permits unrestricted non-commercial use, distribution, and reproduction in any medium, provided the original work is properly cited.

Copyright (c) The Korean Dermatological Association and The Korean Society for Investigative Dermatology 


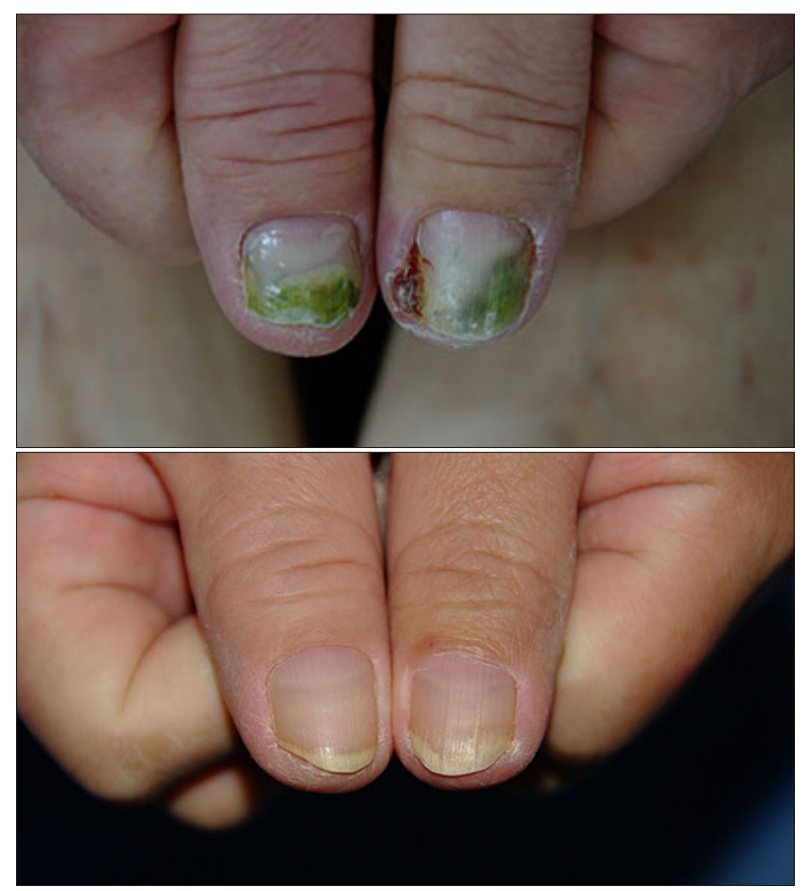

Fig. 1. The patient showed substantial improvement of hand eczema, paronychia and onychodystrophy after six months of treatment.

lar hand eczema on both palms and soles and was treated with alitretinoin $10 \mathrm{mg}$ daily. After six months for alitretinoin, the patient showed substantial improvement of hand eczema, paronychia and onychodystropy (Fig. 1). The patient took alitretinoin with gefitinib for one year and showed improvement with no sign of recurrence. We received the patient's consent form about publishing all photographic materials.

Alitretinoin (9-cis-retinoic acid) is a form of vitamin A which activates both intracellular retinoic acid receptor (RAR) and retinoid $X$ receptor (RXR). It has anti-inflammatory, immunomodulatory effects on the proliferation, and differentiation of keratinocytes. It is approved for treatment of chronic hand eczema which is unresponsive to topical steroids ${ }^{2}$.

Some studies reported alitretinoin treatment for nail lichen planus or nail dystrophy, and the presence of retinoid receptor on the nail matrix has been evaluated as well ${ }^{2-4}$. However, the treatment mechanism for alitretinoin on the nail apparatus diseases has not yet been fully elucidated. We report a case of nail dystrophy with paronychia which was successfully treated with alitretinoin. In an epidermal reaction induced by EGFR inhibitor which is prescribed in many patients who have cancer-especially in paronychiaalitretinoin is more effective than other retinoid agents. Patients with acneiform eruption induced by EGFR inhibitor have been treated with isotretinoin which, however, induces paronychia ${ }^{5}$. On the other hand, alitretinoin improves paronychia and therefore can be treated as a better alternative for nail dystrophy.

We suggest alitretinoin as a treatment option for onychodystrophy induced by EGFR inhibitors.

\section{ACKNOWLEDGMENT}

This study was supported by the National Research Foundation of Korea (NRF) grant funded by the Korea government (MSIP) (No.2016R1C1B1008288).

\section{CONFLICTS OF INTEREST}

The authors have nothing to disclose.

\section{ORCID}

Soo Young Lee, https://orcid.org/0000-0003-3512-3396

Jin-Wou Kim, https://orcid.org/0000-0002-4171-3803

Dong Soo Yu, https://orcid.org/0000-0002-2196-949X

Young Bok Lee, https://orcid.org/0000-0002-8642-2479

\section{REFERENCES}

1. Agero AL, Dusza SW, Benvenuto-Andrade C, Busam KJ, Myskowski P, Halpern AC. Dermatologic side effects associated with the epidermal growth factor receptor inhibitors. J Am Acad Dermatol 2006;55:657-670.

2. Alsenaid A, Eder I, Ruzicka T, Braun-Falco M, Wolf R. Successful treatment of nail lichen planus with alitretinoin: report of 2 cases and review of the literature. Dermatology 2014;229:293-296.

3. Iorizzo M. Nail lichen planus-a possible new indication for oral alitretinoin. J Eur Acad Dermatol Venereol 2016;30: 509-510.

4. Milanesi N, D'Erme AM, Gola M. Nail improvement during alitretinoin treatment: three case reports and review of the literature. Clin Exp Dermatol 2015;40:533-536.

5. Figueiras Dde A, Ramos TB, Marinho AK, Bezerra MS, Cauas RC. Paronychia and granulation tissue formation during treatment with isotretinoin. An Bras Dermatol 2016;91: 223-225. 